Fadlullah/_Ta'dib: Jurnal Pendidikan Islam, Vol. 6 No. 2 (201) 308-320

\title{
PENDIDIKAN ANAK USIA DINI DALAM PERSPEKTIF ISLAM
}

\author{
Fadlullah \\ Universitas Sultan Ageng Tirtayasa \\ Jl. Raya Jak KM.4, Panancangan, Kec. Serang, Kota Serang, Banten 42124 \\ Email: fadlullah421edu@yahoo.com
}

DOI: 10.29313 / tjpi.v6i2.3195

Accepted: November 13th, 2017. Approved: January 18th, 2018. Published: January 18th, 2018

\begin{abstract}
This study attempts to answer questions about early childhood education. In what age range is a person called a child? What educational paradigm is relevant for children? How is the process of educating this early child appropriate according to Islam? The study used literature stud (library research) with content analysis approach. The Qur'an and hadith as the main source are treated as data and studied with the approach of psychology an education theory. Qura'anic themes on human development are aanayed thematically (maudhu'i). From the analysis of several verses of the Qur'an and hadith it an is found that the development of the child starches from birth to the age of puberty marked by ibtilam. In the tradition of Islamic law called Akil baligh. The first seven years of the child's development are an early childhood. At the age range of 0-7 years in the hijriyah number, the child is in phase abliatul wujub. Son of a king who is entitled to excellent education services and has not been burdened with legal obligations. The ultimate achievement of early childhood education is to become an independent individual. Becoming a mumayyiz. who has the basic competence to run Allah's taklif, in the form of worship and the provisions of Sharia norms, able to help oneself and others, dare to make decisions and be able to solve problems wisely, and proud to produce new works. This competence is implanted in the child through a tarbiyah process that emphasizes the actions of the rahmah to guide the child to be empowered with various life skills. On the other hand, the process of values culture is done through a ta'dib process that emphasizes the planting of discipline and orderly culture.
\end{abstract}

Keywords: Early Childhood, Abliyatul Wujub, Mumayyiz:

\section{ABSTRAK}

Penelitian ini berusaha menjawab pertanyaan tentang pendidikan anak usia dini. Pada rentang usia berapakah seseorang disebut anak? Apa paradigma pendidikan yang relevan untuk anak? Dengan cara bagaimanakah proses mendidik anak usia dini yang tepat menurut Islam? Penelitian menggunakan kajian kepustakaan (liberary research) dengan pendektan analisis isi. Al-Qur'an dan Hadits sebagai sumber utama diperlakukan sebagai data dan dikaji dengan pendekatan teori psikologi dan pendidikan. Term-term Al-Qur'an mengenai perkembangan manusia dianalisis secara tematik (maudhu'i). Dari hasil analisis terhadap sejumlah ayat Al-Qur'an dan keterangan hadits yang relevan ditemukan bahwa perkembangan anak merentang dari labir hingga usia puberbas yang ditandai dengan ihtilam. Dalam tadisi hukum Islam disebut aqil baligh. Tujuh tahun pertama perkembangan anak itu disebut anak usia dini. Pada rentang perkembangan usia 0-7 tabun itu, anak ada pada fase abliyatul wujub. Anak laksana raja yang berhak mendapatkan layanan pendidikan secara prima dan belum dibebani kewajiban bukum. Akhir capaian pendidikan anak usia dini adalab menjadi individu mandiri. Menjadi mumayyiz yang memiliki kompetensi dasar untuk menjalankan taklif Allah, berupa peribadatan dan ketentuan norma syariat; mampu menolong diri sendiri dan orang lain, berani mengambil keputusan dan sanggup memecabkan masalah secara bijaksana, serta bangga menghasilkan karya baru. Kompetensi ini ditanamkan kepada anak melalui proses tarbiyah yang menekankan pada tindakan rahmah membimbing anak menjadi berdaya dengan berbagai keterampilan hidup. Di sisi lain, proses pembudayaan nilai-nilai dilakukan melalui proses ta'dib yang menekankan pada penanaman sikap disiplin dan budaya tertib.

Kata Kunci: Anak Usia Dini, Abliyatul Wujub, Mumayyiz: 


\section{PENDAHULUAN}

Pendidikan sering didefinisikan sebagai usaha terencana orang dewasa dalam membimbing anak menuju kedewasaan. Pendidikan bertujuan mengembangkan kemampuan dan rasa tanggung jawab anak dengan bertopang pada kejelasan norma, dasar, dan pedoman bimbingannya. Aktivitas pendidikan harus sesuai dengan tahap perkembangan anak, sehingga dapat menggugah, memotivasi, dan menantang keingintahuan anak. Anak diberi kesempatan untuk memanfaatkan waktu luang, bermain dan bergaul dengan sebaya, berkreasi dan berekreasi sesuai dengan minat, bakat, dan tingkat kecerdasannya. Anak tidak boleh digegas, sehingga lebih cepat mekar dan matang, tetapi kemudian juga cepat layu.

Persoalan yang menjadi fokus penelitian ini adalah apa yang dimaksud dengan anak? Pada rentang usia berapakah seseorang disebut anak dan orang dewasa disekitarnya berkewajiban menjamin dan melindungi hak mereka, mengasuh dan mendidik mereka dengan beragam keterampilan hidup? Apa paradigma pendidikan yang relevan untuk anak? Dengan cara bagaimanakah proses mendidik anak usia dini yang tepat menurut Islam?

Pertanyaan tentang rentang perkembangan anak dari segi legal ada beberapa jawaban, antara lain: sajak dalam kandungan sampai usia pubertas (Abdul Lathif, 1319: 4), layak kerja sekitar usia 15 tahun (Konvensi ILO Nomor 138, yang diratifikasi dalam Undang-undang Republik Indonesia Nomor 20 tahun 1999), siap kawin (UU Nomor 1 tahun 1974), atau berusaha 18 tahun (UU Nomor 23 tahun 2002 tentang Perlindungan Anak). Tentang paradigma pendidikan Islam ada beberapa konsep, antara lain tarbiyah, taklim, ta'dib, tadris, dan tafaqquh (Fadullah, 2005: 11). Pada artikel ini, jawaban digali dari sumber ajaran Islam, Al-Qur'an dan Hadits.

\section{METODE PENELITIAN}

Persepektif Islam dalam penelitian ini adalah Al-Qur'an dan Hadits sebagai sumber ajaran Islam. Penelitian menggunakan pendektan analisis isi, di mana nash Al-Qur'an dan Hadits dikaji dengan pendekatan teori psikologi dan pendidikan yang terintegrasi dengan keyakinan Islam. Penelitian menggunakan kajian kepustakaan (liberary research). Sumber primer dalam kajian ini adalah Al-Qur'an dan hadis nabi. Sedangkan sumber sekunder yang digunakan dalam penelitian ini adalah kitab-kitab tafsir dan syarah hadis serta hasil kajian kalam dan fiqih yang membahas dan berkaitan dengan perkembangan manusia.

Al-Qur'an diperlakukan sebagai data, sebagai suatu dokumen mengenai pedoman hidup yang berasal dari Tuhan (Kuntowijoyo, 1998: 330). Demikian juga dengan hadis nabawiyah sebagai praktikpraktik aktual dan historis petunjukpetunjuk Nabi dan para sahabatnya yang berhasil dikodifikasikan oleh para ahli hadis. Term-term Al-Qur'an mengenai perkembangan anak dianalisis secara secara tematik (maudhu'i) (Abd al-Hay al-Farmawi, 1990: 84), seperti kata nuthfah, 'alaqah, mudhghoh, shoghiro, thifl, balig, rusyd, nikah, 'ajur, syaikhun kabir, arzal al-umur, dan lainlain.

Langkah-langkah yang akan dilakukan adalah mengumpulkan ayat-ayat Al-Qur'an yang berkaitan dengan tema, menghimpun riwayat hadis yang relevan dalam menerangkan pengertian ayat dan tema, ayat-ayat dan hadis itu kemudian disusun dan dirangkai dengan didasarkan pada hubungan yang logis antara satu ayat dengan ayat lainnya yang saling menerangkan.

Kerja selanjutnya merumuskan berbagai pengertian dalam satu kesatuan pandangan Islam yang holistik dan komprehensif tentang tema. Pandangandunia dan etika Islam tentang perkembangan yang disistematisasi itu kemudian diuji dan dijabarkan dalam 
formula-formula teoritis, berdasarkan penemuan-penemuan ilmiah tentang perkembangan manusia (Elizabeth B. Hurlock).

Guna memudahkan pelacakan ayatayat Al-Qur'an yang diperlukan dalam membahas tema, penulis menjadikan kitab al-Mu'jam al-Mufahras li Alfar, al-Quran oleh Muhammad Fuad Abd al-Baqi, sebagai pedoman. Sedangkan untuk pelacakan hadis digunakan kitab al-Mu'jam al-Mufahras li Alfar Hadis al-Nabawiyah oleh A.J. Wensinck. Untuk pedoman analisis semantik adalah kitab Lisan al-'Arabi oleh Imam al-'Allamah Ibn Munzir. Dan untuk pedoman penerjemahan ayat-ayat Al-Qur'an ke dalam bahasa Indonesia dipakai AlQur'an dan Terjemahannya terbitan Departemen Agama Republik Indonesia.

\section{PEMBAHASAN}

\section{Paradigma Pendidikan Anak}

Dalam literatur Islam, konsep pendidikan dikembangkan dari beberapa term, antara lain tarbiyah, taklim, ta'dib, tadris, dan tafaqquh. Setelah dilakukan penelusuran terhadap ayat-ayat Al-Qur'an dan Hadits, konsep taklim, tadris, dan tafaqquh mengacu pada proses belajar orang dewasa, sedangkan term yang relevan untuk pendidikan anak usia dini adalah tarbiyah dan ta'dib. Konsep tarbiyah dan ta'dib berdasarkan Al-Qur'an surat Al-Isra' ayat 24 dan hadits nabi berikut:

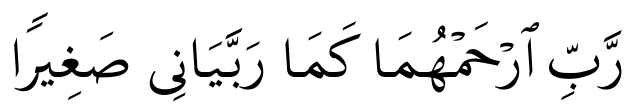

"Ya Tuhan, sayangilah keduaorangtuaku sebagaimana mereka mengasuhku sejak kecil.” (Qs. al-Isra/17: 24).

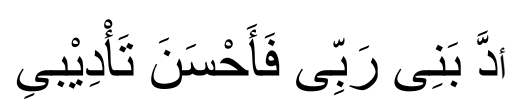

Tuhanku telah mendidikku dengan didikan yang sebaik-baik-nya. [Lihat Jami' al-Ahadits wa al-Marasil (nomor 780 - 781) dan adh-Dha'ifah (nomor 72)]
Tarbiyah, secara etimologis berarti tumbuh dan berkembang (Abdurrahman an-Nahlawi, 1995: 20). Konsep tarbiyah ini secara etimologis mengacu kepada segala sesuatu yang tumbuh, seperti tanaman, anak-anak (manusia) dan spesies yang lain. Pertumbuhan dimaksud mengarah pada dimensi fisiologis dan bersifat kuantitatif. Makna ini dapat dibaca, misalnya, dalam AlQur'an surat asy-Syu'ara [26] ayat 18 yang mengisahkan tentang peran Fir'aun dalam mengasuh Nabi Musa sejak kecil hingga usia sekitar 18 tahun. Dalam konteks ini, mengasuh berarti mencukupi segala kebutuhan meteriil yang mengahantarkan "Musa kecil" pada kekuatan fisik dan peningkatan daya hidup, yang menyebabkan "Musa dewasa" memiliki kemampuan untuk berkembang dan beradaptasi dengan lingkungan serta mampu mempertahankan diri dari segala ancaman/tantangan.

Secara filosofis, Isfahani memahami konsep tarbiyah sebagai proses perkembangan sesuatu dari suatu kondisi ke kondisi tertentu secara bertahap hingga mencapai tingkat kesempurnaan" (Raghib al-Isfahani, tt: 184). Pengertian proses di sini adalah membawa sesuatu dari suatu keadaan kepada keadaan kelengkapan secara berangsur-angsur. Sedangkan pertumbuhan dimaksud menurut Naquib al-Attas, mengacu pada tindakan-tindakan rahmah, seperti mencipta, memelihara, menjaga, memberi, dan mengurus secara tulus (Syed Muhammad Naquib al-Attas, 1994: 71.), hingga cukup umur untuk menikah.

Dalam hal ini, kedewasaan ditandai dengan kesiapan menikah dan kecerdasan mengelola sumberdaya, khususnya uang. Kompetensi ini oleh Al-Qur'an disebut dengan istilah rusyd (Qs. An-Nisa' [4]: 6). Makna "rusyd" meliputi sikap zuhud seperti pengembara yang hemat dan penuh perhitungan dalam mengantisipasi situasi pancaroba. Lawan kata "rusyd" adalah "safab" yang berarti bodoh. Di antara tanda kebodohan itu adalah sikap gegabah, ceroboh, boros dan berlebih-lebihan serta kurang hati-hati yang mendorong seseorang 
mendayagunakan hartanya tidak sesuai dengan pertimbangan akal sehat (Abdullah Lam bin Ibrahim, 2005: 166).

Ta'dib berasal dari kata a-dda-ba, yua-ddi-bu, ta-'-di-y-b yang biasa diartikan dengan 'allama atau mendidik. Arti kata adda-ba secara generik menurut Naquib alAttas adalah undangan kepada suatu perjamuan (Syed Muhammad Naquib alAttas, 1994: 57). Al-Qir'an sendiri dalam suatu keterangan berikut digambarkan sebagai "undangan Allah" dalam perjamuan ruhani di muka bumi.

"Al-Qur'an adalah perjamuan Allah di muka bumi, maka carilah oleh kamu ilmu dari perjamuan-Nya sesuai kesanggupanmu”.

Gagasan perjamuan menyiratkan bahwa si Tuan Rumah adalah seorang yang mulia dan adanya banyak orang yang hadir. Orang yang hadir tentu adalah orang-orang yang menurut si Tuan Rumah pantas memperoleh kehormatan untuk diundang, dan oleh karena itu mereka itu adalah orang-orang yang bermutu dan berpendidikan tinggi. Mereka yang hadir adalah orang yang dapat diharapkan bisa bertingkah laku sesuai keadaan perjamuan, baik dalam berbicara, bertindak, maupun etiket.

Gagasan di atas didukung oleh fakta sejarah periode keemasan Islam. Pada masa itu, istilah ta'dib dalam bentuk subjek pelaku (shighah isim fa'il), yakni kata muaddib digunakan untuk sebutan guruguru privat di Istana yang bertugas mendidik anak-anak bangsawan. Para muaddib mengasuh anak-anak bangsawan dengan membiasakan pola hidup sehat; mendidik tatakrama dan kesusilaan; mengajarkan al-Qur'an dan as-Sunnah sehingga benar-benar mengerti urusan agama dan dapat membedakan antara yang halal dengan yang haram secara tepat; mengajarkan kesusastraan, sejarah dan filsafat, serta retorika dan kepemimpian, sehingga kelak dapat menjadi figur pemimpin yang arif dan bijaksana (M. Athiyah al-Abrasyi, 1970: 141). Belajar filsafat pada zaman itu mencakup logika, matematika (al-Jabar) dan ilmu-ilmu kealaman dan metafisika serta ilmu politik saat ini (Osman Bakar, 1997: 235-2889).

Dalam konsep ta'dib, tujuan pendidikan beranjak dari sekedar transfer of knowladge, dari prinsip ilmu untuk ilmu ke arah ikhtiar menjadikan paradigma hirarki ilmu sebagai landasan tindakan dalam pengambilan keputusan untuk kemanusiaan. Dengan demikian, dapat ditarik pemahaman bahwa visi pendidikan dalam konsep ta'dib meliputi tindakan untuk: (a) mendisiplinkan pikiran dan jiwa; (b) pencapaian kualitaskualitas dan sifat-sifat mulia secara selektif; (c) penyelenggaraan tindakan-tindakan yang benar dan tepat sesuai situasi; (d) penyelamatan diri dari hilangnya kehormatan dengan pemeliharaan kualitas utama tersebut; (e) pemeliharaan semangat intelektual untuk pengembangan ilmu demi kesejahteraan manusia dan kemakmuran bumi, dan; ( $\mathrm{f}$ ) penciptaan iklim lingkungan pendidikan yang kondusif guna menghasilkan manusia yang baik dan kreatif.

Berbeda dengan tarbiyah yang menekankan pada tindakan rahmah, konsep ta'dib tidak dapat dipisahkan dengan upaya pengembangan sikap, pengetahuan, dan keterampilan. Konsep ta'dib, menurut Jusuf Amir Faisal, memandang pendidikan sebagai usaha yang mencoba membentuk keteraturan hirarki ilmu yang berguna bagi diri insan pembelajar sebagai muslim yang harus melaksanakan kewajiban serta fungsionalisasi niat (sistem sikap) yang direalisir dalam kemampuan bertindak teratur, terarah dan efektif (Jusuf Amir Faisal, 1995: 108). Pendidikan secara berangsur-angsur menanamkan ke dalam diri anak karakter nilai luhur, sehingga dapat membimbing ke arah ketaatan kepada Allah dan kompetensi dalam tindakan pelayanan dan pembangunan.

\section{Karakteristik Anak Usia Dini}

Perkembangan manusia dalam perspektif Islam didasarkan pada penafsiran 
Al-Qur'an surat Al-Haij [22]: 5-6, alMukminun [23]: 12-14, al-Rum [30]:54, Ghafir [40]: 67, QS. Al-Nur [24]: 59, dan lain-lain. Dalam hal periodisasi perkembangan didasarkan pada hadits nabi:

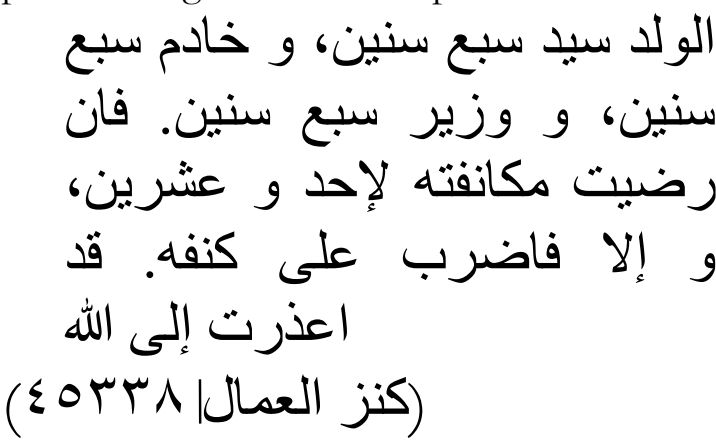

"Anak adalab sebagai tuan selama tujub tabun pertama, sebagai pembantu selama tujub tabun kedua, dan sebagai wazir selama tujuh tabun ketiga. Jika kamu masib mampu membantunya di saat umur dua pulub tabun, bantulah dia. Jika tidak mampu, lepaskanlah dia. Maka selesailah sudah tanggung jawabmu di hadapan ALLAH Ta'ala.” (Kanzul Ummal : 45338)
Ketarangan aya-ayat AlQur'an dan hadits di atas menunjukkan bahwa perkembangan berlangsung secara bertahap, berurutan, terus menerus, dalam tempo perkembangan yang tertentu dan berlaku umum. Pola perkembangan biologis manusia dimulai dari konsepsi hingga lahir (periode pranatal /daur al-Ijtinami), dari makhluk a-seksual (thif) menjadi makhluk seksual - baligh, hingga penurunan jasmani dan menopause (bagi perempuan), menjadi tua (syuyukh) hingga pikun (ardzal al-umur).

Meskipun disadari bahwa Al-Qur'an adalah kitab suci yang berisi wabyu (dan bukan kitab ilmu pengetahuan), namun isyarat ilmiahnya memperlihatkan bahwa pembagian masa perkembangan manusia pada ayat-ayat tersebut bersesuaian dengan gejala alamiah (Elizabeth B. Hurlock). Rentang perkembangan manusia ini dapat digambarkan sebagai berikut:

25 (asyuddah) $40 \quad$ (syuyukh) 60

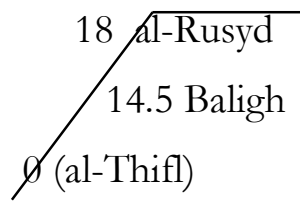

Dalam kajian hukum Islam, rentang kehidupan manusia di atas dibagi dalam dua tahapan luas. Tahapan pertama abliyah alwujub (orang yang tidak memiliki tanggung jawab dan hanya memiliki hak); dan tahapan kedua adalah abliyat al-ada' (orang yang bertanggung jawab bagi pelaksanaan taklif). Masing-masing tahapan terbagi lagi ke dalam dua siklus perkembangan. Tahapan pertama dibagi menjadi dua siklus perkembangan, yakni daur al-ijtinani (anak dalam kandungan) dan daur al-thufulab (anak usia dini). Sedangkan tahapan kedua terbagi menjadi daur al-tamyiz (usia sekolah, 7-14 tahun) dan daur bulugh 'aqil-an (usia pubertas, atau kedewasaan). 
Tabel 1. Perkembangan Kumulatif Tahapan Tanggung Jawab Hukum Menurut Waktu (Yasen Mohamed, 1997: 134)

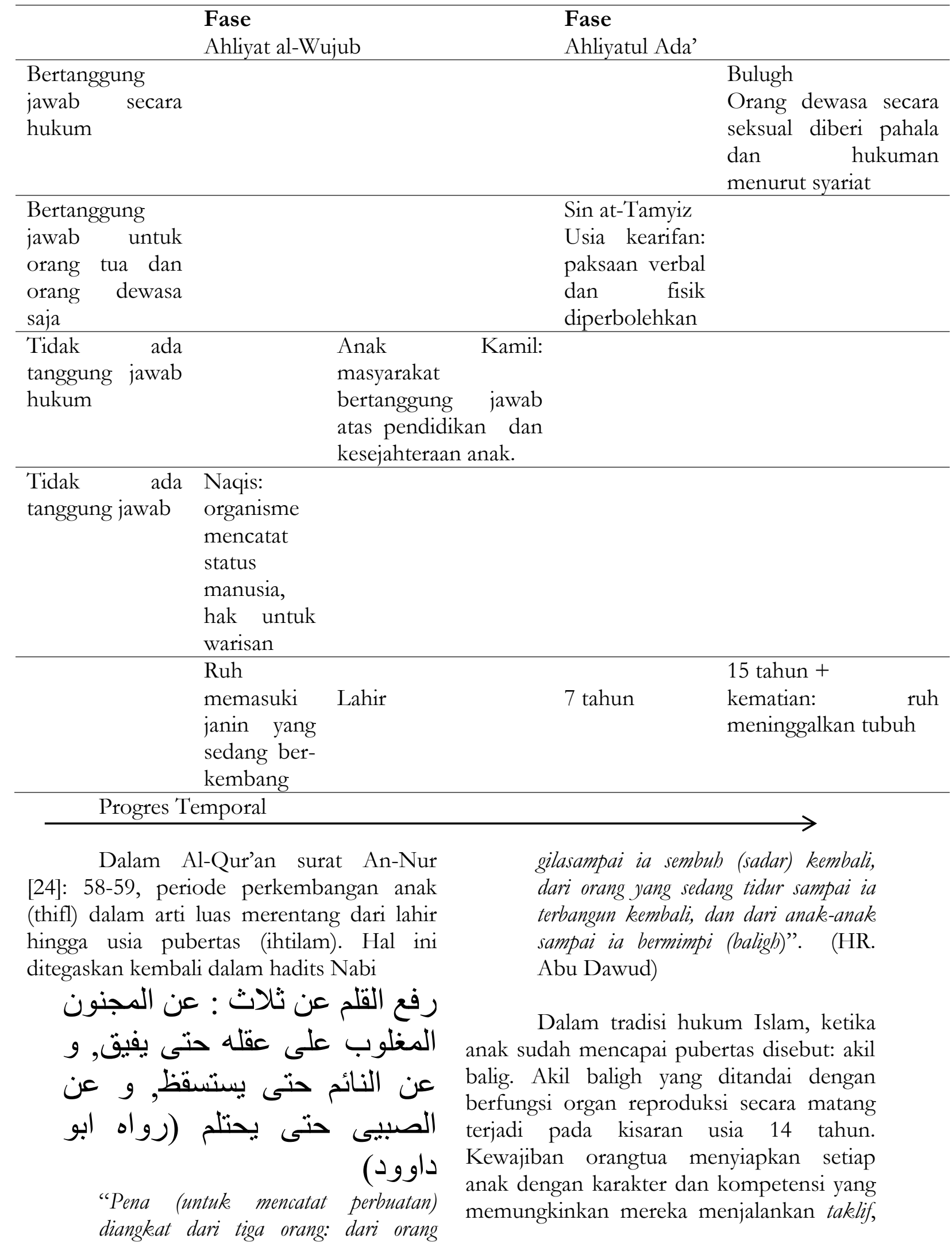


yakni titah ALLAH, saat mereka memasuki usia baligh, sekiatar usia 14 atau 15 tahun.

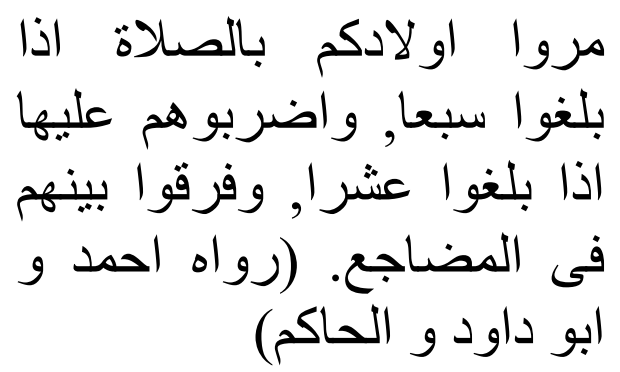

"Perintabkanlah pada anak-anak kalian shalat ketika usia 7 (tujub) tabun dan didiklab dengan keras ketika mamasuki usia 10 (sepulub) tabun. Dan pisabkanlah antara kamu dan mereka dalam hal tempat tidur" (HR. Ahmad, Abu Daud, dan al-Hakim).
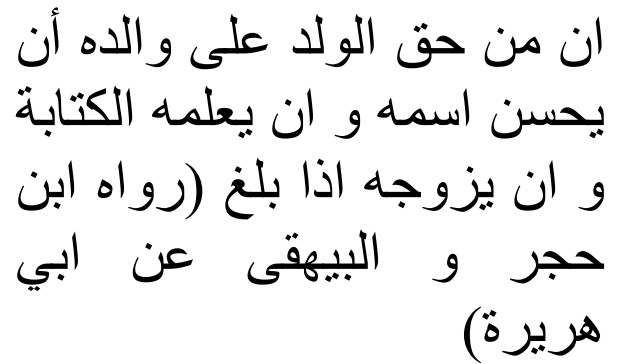

"Sesunggubnya sebahagian dari hak anak atas orang tuanya adalah memberinya nama yang baik, mengajarnya baca tulis, dan menikabkannya jike anaknya itu sudah dewasa" (HR. Ibn Hajar dan Baihaki dari Abi Hurairah)

Dalam hal ini pendidikan fokus pada pengembangan daya cipta akal anak untuk bernalar. Kata al-'Aql (akal) secara etimologis, dalam bahasa Arab berarti alman'u (mencegah) (Al-Qamus al-Muhith, juz IV:19, pasal al-'ain bab lam.). Sebab akal dapat mencegah manusia dari perbuatanperbuatan yang merusak. Sedangkan secara terminologis, berakal berarti kemampuan berpikir abstrak, kemampuan membuat kombinasi, kemampuan untuk menyesuaikan diri dengan lingkungan atau belajar dari pengalaman, kemampuan untuk memecahkan suatu masalah dan mengambil keputusan atau menghasilkan produk dalam lingkup suatu budaya atau komunitas.

Mengikuti pola siklus tujuh tahunan, pada rentang pertmebangan anak dari usia 0-14 tahun di atas terdapat periode anak usia dini (daur ath-Thufulah) pada tujuh tahun pertama, dimulai sejak lahir sampai usia tamyir, sekitar usia 7 tahun hijriyah atau $6^{+}$ tahun masihiyah. Pada tahapan perkembangan anak usia dini status hukum anak ada pada tahap abliyat al-Wujub. Anak ibarat "raja" yang perlu dilayani dan dibimbing orangtua dan guru secara intensif. Orangtua atau guru memberikan bantuan dan rangsangan pendidikan sesuai dengan noramtive development dan ideographic development.

Batas akhir periode perkembangan anak usia dini hingga usia 7 tahun memiliki dua pertimbangan. Pertama, sebagai dasar usia wajib belajar baca tulis Al-Qur'an dan keterampilan akademik lainnya, seperti praktek ibadah, tatakrama sosial, dan keterampilan hidup. Kedua, bahwa ketentuan wajib belajar menimbulkan efek sosial dan psikologi. Muncul harapan-harapan sosial yang menuntut perubahan pola perilaku, minat, dan nilai dalam kebudayaan. Tugas perkembangan anak usia dini dimaksud secara umum adalah sebagai berikut: 
Tabel 2. Tugas perkembangan dan harapan umat Islam terhadap perkembangan anak

\begin{tabular}{|c|c|c|}
\hline $\begin{array}{l}\text { Usia } \\
\text { Anak }\end{array}$ & Fokus Perkembangan & Tugas Perkembangan \\
\hline $\begin{array}{l}0-2 \\
\text { Tahun }\end{array}$ & $\begin{array}{l}\text { Anak belajar mengendalikan } \\
\text { ototnya sehingga secara } \\
\text { berangsur dapat bergantung } \\
\text { pada dirinya (otonom) }\end{array}$ & $\begin{array}{l}\text { - Mendengar Azan dan Iqomah } \\
\text { - Minum ASI (Rodho'ah) hingga sempurna dua } \\
\text { tahun } \\
\text { - Belajar memakan makanan padat } \\
\text { - Belajar bicara } \\
\text { - Belajar mengendalikan pembuangan kotoran } \\
\text { tubuh }\end{array}$ \\
\hline $\begin{array}{l}2-7 \\
\text { Tahun }\end{array}$ & 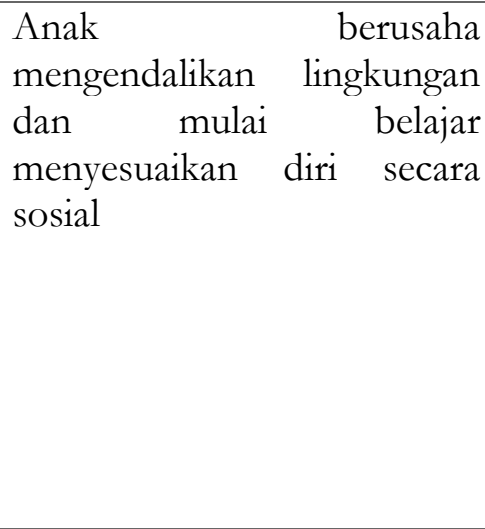 & $\begin{array}{l}\text { - Mempelajari perbedaan seks } \\
\text { - Mempelajari keterampilan fisik yang } \\
\text { diperlukan untuk permainan yang umum } \\
\text { - Mempersiapkan diri untuk membaca dan } \\
\text { menulis } \\
\text { - Belajar membedakan benar dan salah dan } \\
\text { mulai mengembangkan hati nurani } \\
\text { - Mengembangkan pengertian-pengertian yang } \\
\text { diperlukan untuk kehidupan sehari-hari } \\
\text { - Belajar menyesuaikan diri dengan teman- } \\
\text { teman seusianya }\end{array}$ \\
\hline
\end{tabular}

\section{Pendidikan Anak Usia Dini}

Di atas telah dikemukakan bahwa pendidikan bagi anak usia dini didasarkan pada konsep tarbiyah dan ta'dib, pemberdayaan dan pembudayaan. Pemberdayaan terkait dengan kemampuan bertahan hidup sedangkan pembudayaan terkait dengan penanaman sikap disiplin dan budaya tertib. Pemberdayaan dan pembudayaan nilai-nilai agama pada anak usia dini terpatri dalam jiwa anak, membentuk karakter dan kompetensi yang mempengaruhi perkembangan selanjutnya.

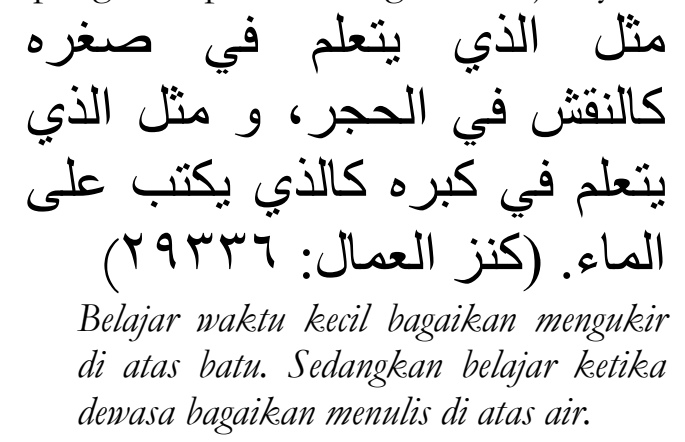

\section{Adversitas dan Keterampilan Hidup}

Menelaah Al-Qur'an surat Al-Ahqof [46] ayat 15 dan surat Lukman [31] ayat 14 menyiratkan bahwa perkembangan anak dipengaruhi oleh kondisi sejak konsepsi dalam rahim ibu. Oleh karena itu, tugas pendidikan mengembangkan kemampuan bertahan hidup sudah dimulai sejak manusia berupa sperma menjadi embrio (M. Imran Pohan, 1986: 5-6). Kemampuan ini terus berkembang secara bertahap seiring dengan meningkatnya keterpisahan dan menurunnya ketergantungan emosional dan fisik anak dengan orangtua, khususnya ibu. Kemandirian anak semakin meningkat seiring meningkatnya keterpisahan anak dengan orangtua (Jerrold Lee Shapiro, 2003: 220), sehingga anak menjadi individu dewasa yang bertanggungjawab.

Pada mulanya anak dalam kandungan, memperoleh nafkah hidup melalui ibu. Bernafas, menerima suhu udara dan nutrisi serba cukup dari ibu. Saat persalinan, tali pusat diputus. Hal ini merupakan ujian ketahanan hidup pertama 
sesaat setelah mengenal dunia fana. Nafkah hidup yang sebelumnya diperoleh langsung melalui tali pusat, setelah kelahiran digantikan dengan pemberian Air Susu Ibu (ASI) melalui mulut. Kemudian, setelah anak berusia dua tahun, Ibu dengan persetujuan Ayah menyapih anak tersebut (Qs. Al-Baqarah [2]: 233.).

Keterikatan bayi dengan ibu pada masa menyusui ini secara psikologis dapat menciptakan rasa percaya (trust), nyaman, aman dan kasih sayang. Namun hal itu tidak boleh menjadi ketergantungan yang terus menerus, dan harus dilepas secara perlahanlahan. Pemberian ASI dikurangi dan digantikan dengan makanan padat secara bertahap, baik dalam jumlah, jenis maupun bentuk makanan itu, sehingga pada usia 24 bulan pemberian ASI dapat dihentikan. Anak mulai dilatih belajar makan dengan tangan sendiri, belajar memegang sendok, cangkir dan minum sendiri, serta mulai dibiasakan toilet training.

Penyapihan pada usia dua tahun ini dimungkinkan oleh dua perubahan penting, yaitu (1) kemampuan untuk bergerak sendiri: berdiri dan berjalan cepat tanpa jatuh dan (2) mulainya ia bicara. Dengan dua langkah ini, terbukalah kemungkinan bagi anak untuk menyelidiki "a sense of self" dan menjelajah lingkungan di sekitarnya, melalui penglihatan, pendengaran, dan rabaan, dengan rasa ingin tahu dan gairah untuk mencoba segalanya.

Anak usia dua tahun, dengan dua kemampuan tersebut mulai percaya diri: "I can do it?". Pada saat yang sama, anak usia dua tahun menemukan kekuatan dari kata "No". Pada tahap ini, anak mempelajari apa yang diharapkan dari dirinya, apakah kewajiban-kewajiban dan hak-haknya disertai pembatasan-pembatasan pada dirinya (Calvin S. Hall \& Gardner Lindzey, 1993: 144). Anak mulai belajar untuk mengontrol diri sendiri dan menerima kontrol dari orang lain dalam lingkungannya (Elizabeth B. Hurlock, 1999: 131). Perubahan ini mengharuskan orangtua untuk bijaksana dengan membimbing anak menenpatkan kata "No?' itu dalam suatu konteks.

Anak secara alamiah memiliki kecenderungan untuk memiliki, meraih dan merebut sesuatu. Ini adalah naluri alamiah untuk bertahan hidup seperti pemburu (Marshall Glickman, 2000: 16). Maka pengasuhan pun bergeser dari sekedar pertukaran tatapan dan suara serta sentuhan ke pola interaksi permainan dan game yang terkait dengan koordinasi motorik (John W. Santrock, 1995: 259). Anak mulai belajar memahami perintah dan aturan, seperti antre, bergantian, memberi dan menerima. Kepatuhan pada perintah, aturan, dan kesediaan berbagi merupakan buah dari pendidikan tentang makna cinta, interdepedensi, kerjasama, dan kesetiakwanan dalam interaksi sosial.

Pada usia 4 tahun anak mulai belajar mengambil inisiatif, membuat rencana, menyelesaikan tugas-tugas dan bertekad meraih tujuan-tujuan. Kegiatan utama anak dalam tahap ini adalah bermain dan dapat dibiasakan untuk membantu pekerjaan sehari-hari yang berhubungan dengan kehidupan keluarga. Anak belajar menolong diri sendiri dan mengurus rumah melalui beberapa bantuan dan supervisi dari orang dewasa. Misalnya membantu mengikat sepatu, makan dengan sendok dan garpu, atau mengancing baju, merapihkan kamar tidur, mencuci piring yang mereka gunakan, dan menyiapkan makanan.

Pada budaya masyarakat desa, anak usia 4-6 tahun sudah dilibatkan untuk melaksanakan tugas pekerjaan orang dewasa, seperti mencari kayu, mengangkat air, menggembala binatang ternak, memanen sayuran, dan mengasuh/menjaga adik-adiknya. Anak perempuan berusia 5 tahun dalam budaya desa harus menuntun, memegang, memeluk, menggendong, dan menjaga adik-adiknya. Sedangkan anak lakilaki mulai belajar mengenal beragam pekerjaan dan profesi dengan mencontoh keterlibatan Ayah dalam komunitas. Dikisahkan Nabi Muhammad sudah belajar menggembalakan kambing sejak usia 4 
tahun ketika berada dalam pengasuhan Halimah dalam budaya desa Sa'd.

Dalam lingkup luas, anak-anak belajar tentang kompetisi, motivasi, ambisi dan dedikasi kerja dengan meniru dan bermain peran sebagai guru, polisi, petani, nelayan, teller bank, pekerja sosial dan ragam profesi lainnya dengan menggunakan imajinasi dan fantasi. Mereka belajar melalui kegiatan bermain dengan memanfaatkan alat peraga dan media, seperti TV, Radio, dan buku (June Thompson, 2003: 56).

Pada akhir periode anak usia dini, kegiatan bermain secara berangsur digantikan dengan belajar mengembangkan kecakapan kerja. Pada usia $6+$ atau 7 tahun, anak berbakat disebut mumayyiz. Mumayyizmeminjam istilah Robert T. Kiyosaki berarti kemampuan membuat distingsi yang lebih baik (Robert T. Kiyosaki, 2005: 22); kemampuan membuat perbedaan yang lebih jelas. Membedakan antara kebutuhan dan keinginan (syahwat), halal dan haram, hemat dan kikir, derma dan boros, penambahan dan pengurangan, perkalian dan pembagian, aset dan leabilitas, tabungan baik dan tabungan buruk, pengeluaran baik dan pengeluaran buruk, utang baik dan utang buruk, pemasukan baik dan pemasukan buruk, investasi baik dan investasi buruk. Dengan kata lain, anak dikatakan "cerdas" ketika ia menemukan cara untuk memilah atau membuat distingsi segala sesuatu dengan cepat.

Lebih khusus, menurut Abu Hanifah, mumayyiz adalah anak yang mampu memahami jual beli (perdagangan) dan ia mengetahui bahwa menjual itu mencabut hak pemilikan atas barang yang dijual, sebaliknya membeli dapat menarik hak pemilikan lewat harga yang diberikan. Anak juga dapat mengetahui dan membedakan antara penipuan yang keji dengan "penipuan sedikit" - seperti dalam promosi, yang dengan akad itu dimaksudkan akan tercapai keuntungan dan penambahan (Huzaemah Tahido Yanggo, 2004: 208). Mumayyiz [dengan bantuan supervisi orangtua] dipandang kompeten (ahliyah) melakukan kegiatan bisnis, berjual beli secara praktis dan mendatangi pasar serta ikut terlibat dalam menentukan "harga". Kompetensi ini diketahui ketika anak dapat berbicara untuk membedakan dan menjelaskan berbagai hal, terutama terkait dengan perbedaan harga atau nalai suatu barang dan jasa.

\section{Karakter Disiplin dan Budaya Tertib}

Dalam Al-Qur'an surat al-Baqarah [2] ayat 128, surat Ibrahim [14] ayat 40, surat al-Furqan [25] ayat 74, surat ashShofat [37] ayat 100, dan surat Al-Ahqaf [46]: 15 menunjukkan bahwa doa orangtua terhadap anaknya selalu terkait dengan cita anak sholeh, menjadi imam, rajin sholat, dan patuh terhadap aturan agama. Inilah yang menjadi dasar pembinaan kedisiplinan dan budaya tertib.

Karakter disiplin dibiasakan melalui pelaksanaan ibadah sholat. Interaksi anak dengan anggota keluarga, belajar Al-Qur'an, dan tidur dirancang berdasarkan ketentuan jawdal sholat. Pola makan seperti tercermin dalam kegiatan amaliah Ramadhan juga didasarkan pada jadwal sholat. Makan sahur sebelum subuh dan makan berbuka saat memasuki waktu Maghrib. Sedangkan budaya tertib dilakukan dengan membiasakan prinsip pahala (reward) bagi amal saleh (prestasi) dan hukuman (punishment) terhadap perbuatan jelek. Lebih lanjut, karakter disiplin dan budaya tertib ini menjadi dasar pengembangan keterampilan sosial: berteman (bersahabat), berbagi (penerimaan, penghargaan, kemandirian), menunggu giliran, mematuhi rambu atau aturan yang ada, dan bertanggung jawab, baik di rumah, sekolah dan masyarakat.

Anak usia dini belajar bagaimana bertindak dengan meniru pembicaraan dan tindakan orang dewasa, tanpa mengetahui mengapa. Anak usia dini tidak mampu mengerti masalah standar moral, sehingga orangtua perlu konsisten dengan aturan dan membimbing anak untuk belajar berperilaku moral dalam pelbagai situasi yang khusus. 
Perkembangan intelektual anak usia dini belum mencapai titik di mana ia dapat mempelajari atau menerapkan prinsipprinsip abstrak tentang benar dan salah. Dalam kondisi ini, jika anak melanggar aturan, maka orangtua atau guru perlu memberi maaf disertai penjelasan dialogis yang dapat membimbing anak mengubah perilaku.

"Diriwayatkan dari Wabb bin Kaisan, ia mendengar Umar bin Abu Salamah berkata: "Waktu itu aku masib anak-anak di bawah asuban Rasulullah $S A W$ (Ketika sedang makan) tanganku bergerak ke mana-mana di atas piring. Melihat hal ini kemudian Rasulullah berkata kepadaku, "Hai anak muda! Bacalab basmalah terlebih dabulu. Makanlah dengan tangan kananmu dan makanlah apa yang ada di dekatmu”. Sungguh, nasehat Rasulullah tersebut selalu menjadi pola makanku selanjutnya. (HR. Bukhari)

Tidak ada manusia yang tidak pernah salah. Demikian juga dengan anak. Kebanyakan pelanggaran anak berhubungan dengan belum matangnya kognisi anak. Oleh karena itu, Islam mengajarkan bahwa pelanggaran yang dilakukan anak tidak berdampak hukum. Yang dibutuhkan adalah pendidikan, bimbingan, dan keteladanan. Secara psikologis, pelanggaran etik oleh anak usia dini disebabkan tiga hal (Elizabeth B. Hurlock, 1999: 126): (1) Ketidaktahuan. Anak melakukan pelanggaran karena belum mengerti mana perilaku benar dan salah yang tidak dibenarkan oleh kelompok sosial. Anak diberitahu mengenai peraturan tetapi mungkin lupa atau tidak mengerti dalam situasi-situasi apa peraturan itu berlaku; (2) Sengaja berbuat salah. Anak membuat suasana ribut atau tidak patuh dalam hal kecil untuk memperoleh perhatian. Sebaliknya, ia tidak mempunyai dorongan untuk mengikuti peraturan-peraturan karena tidak mengerti manfaatnya sebagai anggota kelompok sosial; dan (3) Kebosanan. Bila anak tidak mempunyai kegiatan untuk mengisi waktu luang, maka ia membuat ulah yang menguji kesabaran dan kuasa orang dewasa dalam menegakkan disiplin.

Fenomena lupa terjadi karena working memory anak-anak masih cenderung pada ingatan jangka pendek (short-term memory), meskipun mereka sangat cerdas. Anak hanya mengingat peristiwa (eposodic memory), bukan pengetahuan tentang fakta (semantic memory), sehingga belajar bagaimana berperilaku sosial yang baik merupakan proses yang panjang dan sulit. Meskipun suatu hari anak usia dini mengangguk dan berjanji untuk tidak melakukan sesuatu, tetapi keesokan hari atau dua hari sesudahnya mungkin ia lupa. Jadi anggapan orang dewasa sebagai tindakan tidak patuh seringkali hanya merupakan masalah lupa.

Kebiasaan untuk patuh harus dibentuk agar anak usia dini mempunyai disiplin yang konsisten. Untuk itu, hukuman (sanksi) diizinkan bagi anak yang terbukti dengan sengaja melanggar aturan dalam kerangka pendidikan. Hukuman (sanksi) hanya diberikan jika tidak ada cara lain untuk menyampaikan larangan atau anak melakukan perbuatan terlarang. Setiap pelanggaran diberi satu sanksi ringan yang setara, tidak boleh lebih. Hukuman ganda harus dihindari. Jika Ayah sudah menghukum, Ibu tidak boleh ikut menghukum.

Hukuman disesuaikan dengan "kejahatan". Anak harus mengerti mengapa ia dihukum. Hukuman yang diberikan berhubungan dengan kesalahan perbuatannya. Teguran atau sanksi diberikan agar anak mengerti kekeliruannya dan mengambil sikap untuk tidak mengulangi kesalahan yang sama. Jika anak melakukan satu pelanggaran, secara sengaja, tetapi dibiarkan dan tidak ditegur, maka hal ini akan mendorong anak untuk terus mempertahankan perilaku yang salah. Tidak merasa bersalah atau malu bila melakukan sesuatu yang diketahui sebagai sesuatu yang salah. Malahan ia berusaha membenarkan perbuatannya untuk menghindari hukuman.

Selain teguran, bentuk hukuman yang umum digunakan orangtua mencakup 
hukuman badan berupa tepukan, pukulan dan cambukan lidi; melarang keistimewaan seperti menonton acara TV yang digemari; mengucilkan anak-anak di kamar; menyuruh tidur, kadang-kadang tanpa makan; menyuruh duduk di "kursi penjahat" di pojok ruangan sehingga semua orang dapat melihat; mengancam untuk meninggalkannya atau tidak mencintainya; membandingkan dengan saudara-saudara yang lebih baik; mengomeli dan berulangulang mengomentari pelanggarannya. Dalam Islam, hukuman badan diperkenankan asal tidak melukai yang menyebabkan cedera, dan tidak menyarankan hukuman yang mengoyak "jiwa" anak, seperti mempermalukan anak di muka umum.

Islam mengajarkan penegakan disiplin secara konsisten. Sanksi atas suatu pelanggaran harus jelas, disepakati, dan berlaku untuk semua. Anak perlu mengerti mengapa ia dihukum! Sebaliknya, jika anak melakukan kebaikan diberikan hadiah 7 kali lipat, 10 kali lipat, 70 kali lipat, dan seterusnya. Hadiah tidak harus berupa barang, tapi dapat berupa pujian atau penghargaan sosial yang meninggikan harga diri anak. Meskipun aturan disiplin harus ditegakkan, tetapi Islam cenderung pada hadiah, motivasi, dan permaafan (baca: taubat). Anak yang sering dihukum dari pada diberi hadiah cenderung pada amarah (cemberut), berontak (keras kepala), dan negativistik (ingin "menantang" orang yang menghukumnya). Anak yang sering ditegur untuk hal-hal sepele cenderung tidak mau mendengarkan lagi. Demikian juga anak yang sering dihukum fisik cenderung melahirkan sifat agresif dan menjadi kurang peka terhadap tujuan hukuman, yakni menyesali perbuatan salahnya dan berjanji untuk tidak mengulangi.

Dalam tataran praktis, menyeimbangkan antara hukuman dan pujian, menyayangi dan memanjakan terkadang sulit dilakukan. Bertindak adil, arif, dan bijakasana sebagaimana diajarkan agama tidak selalu mudah dijalankan. Tidak jarang, orangtua gagal menghadapi ujian kesabaran dari anaknya. Orangtua cenderung mendisiplinkan anak usia dini dengan disiplin ketat (baca: otoriter) atau sebaliknya disiplin lemah. Dalam disiplin yang bersifat otoriter, orangtua menetapkan peraturan-peraturan dan memberitahukan anak bahwa ia harus mematuhi peraturanperaturan tersebut. Tidak ada usaha untuk menjelaskan pada anak, mengapa ia harus patuh dan anak tidak diberi kesempatan untuk mengemukakan pendapat tentang adil tidaknya peraturan-peraturan.

\section{KESIMPULAN}

Perkembangan anak usia dini merentang dari lahir hingga usia 6 tahun Masihiyah atau 7 tahun Hijriyah. Pada rentang perkembangan ini anak ada pada fase abliyatul wujub yang berhak mendapatkan pendidikan yang memberdayakan. Anak belum dibebani kewajiban.

Paradigma pendidikan anak usia dini mengacu pada konsep tarbiyah dan ta'dib. Pendidikan pada konsep tarbiyah menekankan pada tindakan rahmah, di mana orangtua atau guru wajib menumbuhkan rasa berdaya dan mengembangkan kemandirian secara bertahap mulai keterampilan mengurus diri sendiri, mengerjakan pekerjaan rumah, keterampilan bermain dan belajar. Sedangkan ta'dib mengacu pada proses pembudayaan nilai-nilai, khususnya sikap disiplin dan budaya tertib. Pemduayaalan dilakukan melalui pembiasaan disiplin sesuai dengan jadwal sholat serta pemberian pujian dan hukuman.

Akhir capaian pendidikan anak usia dini adalah menjadi individu mandiri. Menjadi Mumayyiz, yang mampu menolong diri sendiri dan orang lain, berani mengambil keputusan dan sanggup memecahkan masalah secara bijaksana, serta bangga menghasilkan karya baru. Anak memiliki kompetensi dasar untuk 
menjalankan taklif Allah, berupa
peribadatan dan ketentuan norma syariat.

DAFTAR PUSTAKA

Al-Abrasyi, M. Athiyah. (1970). Dasar-dasar Pokok Pendidikan Islam, Jakarta: Bulan Bintang.

Al-Attas, Syed Muhammad Naquib. (1994). Konsep Pendidikan dalam Islam, Bandung: Mizan.

Al-Isfahani, Raghib. (tt). Mu'jam Mufradat Alfadzal-Qur'an, Beirut: Dar al-Fikr.

An-Nahlawi, Abdurrahman. (1995). Pendidikan Islam di Rumah, Sekolah, dan Masyarakat, Jakarta: Gema Insani Press.

Bakar, Osman. (1997). Hirarki Ilmu, Bandung: Mizan.

Djalal, Abdul Djalal. (1990). Urgensi Tafsir Maudhu'i pada Masa Kini, Jakarta: Kalam Mulia.

Fadullah. (2005). Quo V adis Pendidikan Islam: Analisis Tujuan dan Program Pendidikan Islam Sepanjang Hayat. Serang: Untirta Press.

Faisal, Jusuf Amir. (1995). Reorientasi Pendidikan Islam, Jakarta: Gema Insani Press.

Glickman, Marshall. (2000). The Mindful Money Guide, [Terjemah: Soesanto Boedidarmo], Jakarta: Elex Media Komputindo.

Hall, Calvin S, dkk. (1993). Teori-teori Pskilodinamike (Klinis), Jogjakarta: Kanisius.

Hurlock, Elizabeth B. (1999). Psikologi Perkembangan, Jakarta: Erlangga.
Ibrahim, Abdullah Lam. (2005). Fiqih Finansial, Jakarta: Era Intermedia.

Kiyosaki, Robert T. (2005). Rich Kid Smart Kid, [Terjemah: J. Dwi Helly Purnomo \& Rina Buntaran]. Jakarta: Gramedia.

Kuntowijoyo. (1998). Paradigma Islam: Interpretasi untuk Aksi, Bandung: Mizan.

Lathif, Abdul, dkk. (1819H). Bayan al-Arkan li Abli al-Islam wa al-Iman. Cibeber Banten: Mathbaah al-Anwar.

Mohamed, Yasen. (1997). InsanYang Suci: Konsep Fitrah dalam Islam, Bandung: Mizan.

Santrock, John W. (1995). Life-Span Development Perkembangan Masa Hidup) Jild I., Jakarta: Erlangga.

Shapiro, Jerrold Lee. (2003). The Good Father: Kiat Lengkap Menjadi Ayah Teladan, Bandung: Kaifa.

Thompson, June. (2003). Toddlercare: Panduan Merawat Balita, Jakarta: Erlangga.

Pohan, M. Imran. (1986). Menyongsong Masa Depan. Jakarta: Intermedia.

Undang-undang Republik Indonesia Nomor 20 tahun 1999 tentang Perlindungan anak.

Undang-undang Republik Indonesia Nomor 1 tahun 1974 tentang Perkawinan.

Undang-undang Republik Indonesia Nomor 23 tahun 2002 tentang Perlindungan Anak.

Yanggo, Huzaemah Tahido. (2004). Fiqih Anak, Jakarta: Al-Mawardi. 